\title{
Performance of cross laminated timber panels made of Pinus oocarpa and Coffea arabica waste
}

\author{
Ana Carolina Corrêa Furtini ${ }^{1}$ D, Carolina Aparecida dos Santos ${ }^{1}$ (D), Hudson Venâncio Silva Garcia ${ }^{2}$ (D), Flávia Maria Silva Brito ${ }^{3}$ (D), \\ Thalita Paula dos Santos ${ }^{4}$ D, Lourival Marin Mendes² $^{2}$, José Benedito Guimarães Júnior ${ }^{2}$ (D)
}

${ }^{1}$ Centro Universitário de Lavras/UNILAVRAS, Departamento Engenharia Civil, Lavras, MG, Brasil

${ }^{2}$ Universidade Federal de Lavras/UFLA, Departamento Engenharia de Biomateriais, Lavras, MG, Brasil

${ }^{3}$ Universidade de São Paulo/USP, Departamento Recursos Florestais, Piracicaba, SP, Brasil

${ }^{4}$ Universidade Federal de São João del-Rei/UFSJ, Departamento Engenharia Mecânica, São João del-Rei, MG, Brasil

Contact authors: carol.furtini@gmail.com; carolinaapnep@gmail.com; hudsonjapa@hotmail.com; faengflorestal@gmail.com; thalitasantospp@hotmail.com; lourival@ufla.br; jose.guimaraes@ufla.br

Received in November 24, 2020 and approved in May 21, 2021

\section{ABSTRACT}

The growth of the civil construction sector, made necessary to develop alternative products made of sustainable materials. Within this context came the cross laminated timber panels (CLT), which are formed by gluing veneer arranged at $90^{\circ}$, which provide high strength and great versatility, as constructive elements. This research aimed to evaluate the chemical properties of the particles of both materials and evaluate the performance of CLT panels made with Pinus oocarpa and waste wood from Coffea arabica. The panels were made with three orthogonal layers with veneer of pine and coffee wood, using the phenol-formaldehyde (PF) adhesive with a spread rate of $0.35 \mathrm{kgm}^{-2}$ and the hydraulic press with a pressure of $1,2 \times 10^{7} \mathrm{~N} . \mathrm{m}^{-2}$ for 15 min. The physical, mechanical properties, acoustic and thermal performance of the panels were evaluated. There was a significant difference for water absorption in 2 and 24 hours. The panels produced only with coffee wood waste showed the lowest water absorption rates, corresponding to 10.2 and $33.3 \%$, in 2 and 24 hours. In relation to the $\mathrm{MOE}$, the panels made with varied veneer were statistically equivalent to each other and the panels made of pine blades

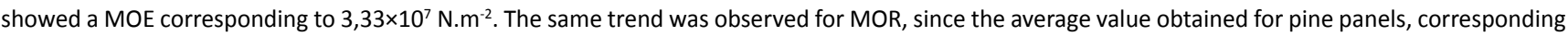
to $1,35 \times 10^{8} \mathrm{~N} \cdot \mathrm{m}^{-2}$ was significantly higher. Panels made of coffee veneer and pine veneer showed no delamination. With regard to acoustic and thermal evaluation, all panels met the minimum requirements indicated in the standards, with emphasis on coffee wood waste, associated or not with pine wood.

Key words: Adhesive; Coffee; Chemical analysis; Hybrid panel; Technological properties.

\section{INTRODUCTION}

The cross laminated timber panels (CLT) are engineered products made up of solid wood veneer arranged in layers with alternating orientation, orthogonal to the neighboring layers, joined by bonding (He; $\mathrm{Su}$; Li, 2018). In which, they allow a fast, dry, clean and high precision construction, providing all the subsequent conditions for assembly and easy installation (Ringhofer, 2018). They have similar mechanical properties in orthogonal directions, in addition to great resistance and rigidity in the plane, good acoustic and thermal performance, and a high level of prefabrication, suitable and competitive characteristics for homes and/or buildings (He; Su; Li, 2018).

França and Bogo (2019) evaluated the environmental comfort in buildings built in CLT and in traditional construction systems. They concluded that investment in wooden buildings is the only renewable and easy to use construction material, in which new buildings should invest in these materials as insulators for their construction. The building will certainly present a better thermal performance and will need less electronic equipment to guarantee the thermal quality of its interior. In terms of factories producing CLT in the country, so far, there is information from a manufacturer that started production in 2012, in the state of São Paulo (Betette; Castilho, 2019).
The CLT study highlights the importance of the adhesive. Marques et al. (2020) state that this component is the most important part of a glued joint and emphasize that it depends on the formulation, preparation and application. Among the most requested, phenol-formaldehyde stands out, which is one of the main types of synthetic thermoset adhesive used by the wood panel industries. Widely used in the production of panels for structural purposes intended for the external environment, with or without protection (Iwakiri et al., 2019).

It is possible to transform low-value wood into high added value products, providing better use of forest resources for the construction of CLT-type panels, which is why they are said to be promising in the construction sector (Mallo; Espinoza, 2015). Among these options stands out the coffee culture, which occupies a diversity of regions, variety of climates, reliefs, altitudes and latitudes. The first survey of the 2021 coffee crop, estimates a total production of 43.8 million and 49.5 million bags (conilon and arabica) (Companhia Nacional de Abastecimento - CONAB, 2020).

The activity of coffee production, in addition to significantly contributing to regional economic and human development, has a great potential for generating waste that can be used economically. (Berni; Manduca, 2020). Some works have already been carried out with the objective of 
taking advantage of the waste of coffee wood and adding value to this waste, such as: Rachtanapun, Sattayarak and Ketsamak (2012), Leite et al. (2014) and Pereira et al. (2014) and another option for the use of coffee wood waste would be in the production of cross-laminated wood panels, as it is a low added value waste, used until then to generate energy, so that the raw material would be economically viable, in addition to contributing to the civil construction sector.

It is known, however, that pine wood is used in the civil construction sector, mainly as a substitute for native wood, and it is also a raw material widely used for panel manufacturing. Pinusoocarpa comes from Central America and Mexico. It produces wood and resin for commercial purposes, in addition to seeds, which facilitates its expansion (Calil Neto et al., 2016).

According to some researchers, the CLT, despite being marketed with large dimensions, does not require that the material from which it is produced have high dimensions. The use of adhesives on side and top bonding, in addition to jagged splices, can be an option to overcome such problems, which would not harm the essence of this research. According to Bowyer et al. (2016), CLT has the advantage of using lower quality wood, which can be manufactured with low quality or small diameter wood, usually underutilized wood.

The study of the hybrid CLT of coffee wood with pine is interesting because allows the combination of the properties of different materials in a composite, which can result in improvements in quality and final performance. The economic factor is also noteworthy, since working with residual coffee wood, would lower the cost of producing the panels. Furthermore, using this waste implies in the manufacture of a product with greater added value, since the wood is used in large part for power generation.

In this context, the objective was to evaluate the chemical properties of the particles of both materials and to evaluate the performance of CLT panels made with Pinus oocarpa and Coffea arabica wood waste.

\section{MATERIAL AND METHODS}

\subsection{Origin and Collection of Raw Materials}

For the development of this research, we used pine wood and woody coffee waste. The pine wood came from experimental plantations at the age of 28, collected on the campus of the Federal University of Lavras (UFLA), located in the city of Lavras, MG, at the coordinates of $21^{\circ} 14^{\prime}$ 'south latitude and $45^{\circ} 00^{\prime}$ 'west longitude, with an altitude of $900 \mathrm{~m}$. Wood coffee wastes from 13-year-old plantations were collected in the municipality of Nepomuceno, MG, located in the Campo das Vertentes mesoregion, at $21^{\circ} 14^{\prime}$ south latitude and $45^{\circ} 14^{\prime}$ west longitude, at an altitude of $864 \mathrm{~m}$. The material collected was 13 years old.
The Pinus oocarpa wood was processed in the laboratory of the Experimental Unit for the Production of Wood Panels (UEPAM), located at UFLA and transformed into planks, with the aid of a circular saw and a thicker to standardize thicknesses. Subsequently, the material was resized to produce the veneer, which would be used in the proposed tests. In relation to coffee wood, we gave preference to wastes, which did not contain any signs of deterioration or tortuosity. After selecting the material, it was transformed into slats, which would give origin to the veneer. The final dimensions of the veneer were $25 \mathrm{~cm} \times 5$ $\mathrm{cm} \times 1 \mathrm{~cm}$ (length $\mathrm{x}$ width $\mathrm{x}$ thickness, respectively). They were stored in an oven until they reached $8 \%$ moisture content, within the range established by Iwakiri (2005) between 6 and 12\%and then reserved for the manufacture of the panels.

\subsection{Determination of the basic density of raw materials timber}

The basic density was performed according to the guidelines of NBR 11941 (Associação Brasileira de Normas Técnicas - ABNT, 2003), using the immersion method and calculated according to Equation 1.

$\mathrm{D}_{\mathrm{b}=} \mathrm{M}_{3} /\left(\mathrm{M}_{2}-\mathrm{M}_{1}\right)$

In which:

$\mathrm{D}_{\mathrm{b}}=$ Is the basic density of the wood $\left(\mathrm{kg} \cdot \mathrm{m}^{-3}\right)$

$\mathrm{M}_{3}=$ Mass of the sample oven dried at $105 \pm 2{ }^{\circ} \mathrm{C}$

$\mathrm{M}_{2}=$ Weighing mass of the immersed set (wood chips + container)

$M_{1}=$ Mass of the immersed container

\subsection{Chemical analysis of the timber}

To determine the chemical components of the raw materials used, we split the wood into circular saws and crushed it in a hammer mill to obtain particles. Later, they were transformed into sawdust in a Willey type mill. The sawdust obtained was classified and the material was selected with a 60 mesh size.

The total extractives content was quantified based on NBR 14583 (ABNT, 2010a). For the analysis of the insoluble lignin content, we followed the recommendations of NBR 7989 (ABNT, 2010b). To determine the ash content, we adopted the procedures of NBR 13999 (ABNT, 2017). The percentage of holocellulose was obtained by adding the levels of extractives, lignin and ash, subtracted from 100, as shown in Equation 2.

Holocellulose $(\%)=100-$

$-($ Total extractives + Lignin content + Ash $)$ 


\subsection{Production of CLT Panels}

We adopted the following dimensions for the experimental panels: $0.25 \mathrm{~m} \times 0.25 \mathrm{~m} \times 0.30 \mathrm{~m}$ (length $\mathrm{x}$ width $\mathrm{x}$ thickness, respectively). For the manufacturing process, we used phenol formaldehyde (PF) adhesive for a few reasons such as: availability in the laboratory, great requirement in the market and good features such as: excellent thermal behavior, high level of strength and resistance, resistance to humidity, cost, being widely used for outdoor environments, long thermal and mechanical stability, excellent ability to act as electrical and thermal insulator.

According to the technical sheet, made available by the adhesive donor company, the characteristics were: solids content of $52 \%, \mathrm{pH}$ of 7.56 , gelatinization time of 124 seconds and viscosity of $645 \mathrm{Cp}$. To measure the spread rate, the area of the veneer in $\mathrm{m}^{2}$ was measured and then the amount of grams needed for each veneer was calculated. The adhesive was used with a spread rate of $0.35 \mathrm{~kg} \cdot \mathrm{m}^{-2}$ in a double line. The adhesive was applied with the help of a spatula on the surface of the clean veneer and then placed in adjacent layers. The average temperature in the place was $25.5^{\circ} \mathrm{C}$ and the relative humidity was $37 \%$.

The panels were hot pressed, in a hydraulic press with a pressure of $1,2 \times 10^{7} \mathrm{~N} \cdot \mathrm{m}^{-2}$ for $15 \mathrm{~min}$ and temperature of $150{ }^{\circ} \mathrm{C}$. After pressing the panel was taken to the air conditioning room where it would be squared and subjected to tests. For this study, we performed shear tests on the glue line, delamination, MOR, MOE. Thus, 16 experimental panels with three orthogonal layers were manufactured (Figure 1). The choice of the number of panels was based on the amount of material available in the laboratory.

\subsection{Evaluation of physical and mechanical properties}

For physical characterization, the following properties were determined: apparent density (12\%) and moisture content according to the procedures defined in Annex B of the Brazilian Regulatory Standard - NBR 7190 (ABNT, 1997). To determine water absorption in 2 and 24 hours of immersion, we followed the requirements of ABNT NBR 9486 (2011).

For each physical property, eight samples were used, totaling 32 tested units.

For mechanical characterization, the following properties were determined: modulus of rupture (MOR), modulus of elasticity (MOE) to static bending, shearing in the glue line and delamination test. The flexion test was performed according to the procedures of ABNT NBR 9535 (ABNT, 2012) with some adaptations, depending on the size of the panels, which had dimensions of $0.25 \times 0.04 \times 0.03 \mathrm{~m}$ (length $\mathrm{x}$ width $\mathrm{x}$ thickness) and the span was $0.185 \mathrm{~m}$. The EMIC universal testing machine, model DL-30000 with a load capacity of $300 \mathrm{kN}$, with a test speed of 0.005 m.min-1 was used. In total, 16 samples were taken.

The shear tests on the glue line were carried out in accordance with NBR ISO 12466-1 (ABNT, 2006) adapted according to the size of the panels. The dimensions of the samples were equivalent to $0.1 \times 0.030 \times 0.030 \mathrm{~m}$ (length $\mathrm{x}$ width $x$ thickness). Two grooves were studded in each sample in the upper and lower positions with distances of $0.025 \mathrm{~m}$, as shown in Figure 2. The tests were performed on the universal testing machine EMIC with a loading capacity of 30 tons, with a loading speed of $120 \mathrm{~N} . \mathrm{s}^{-1}$. For this test, 8 samples were tested per treatment, thus totaling 32 units.

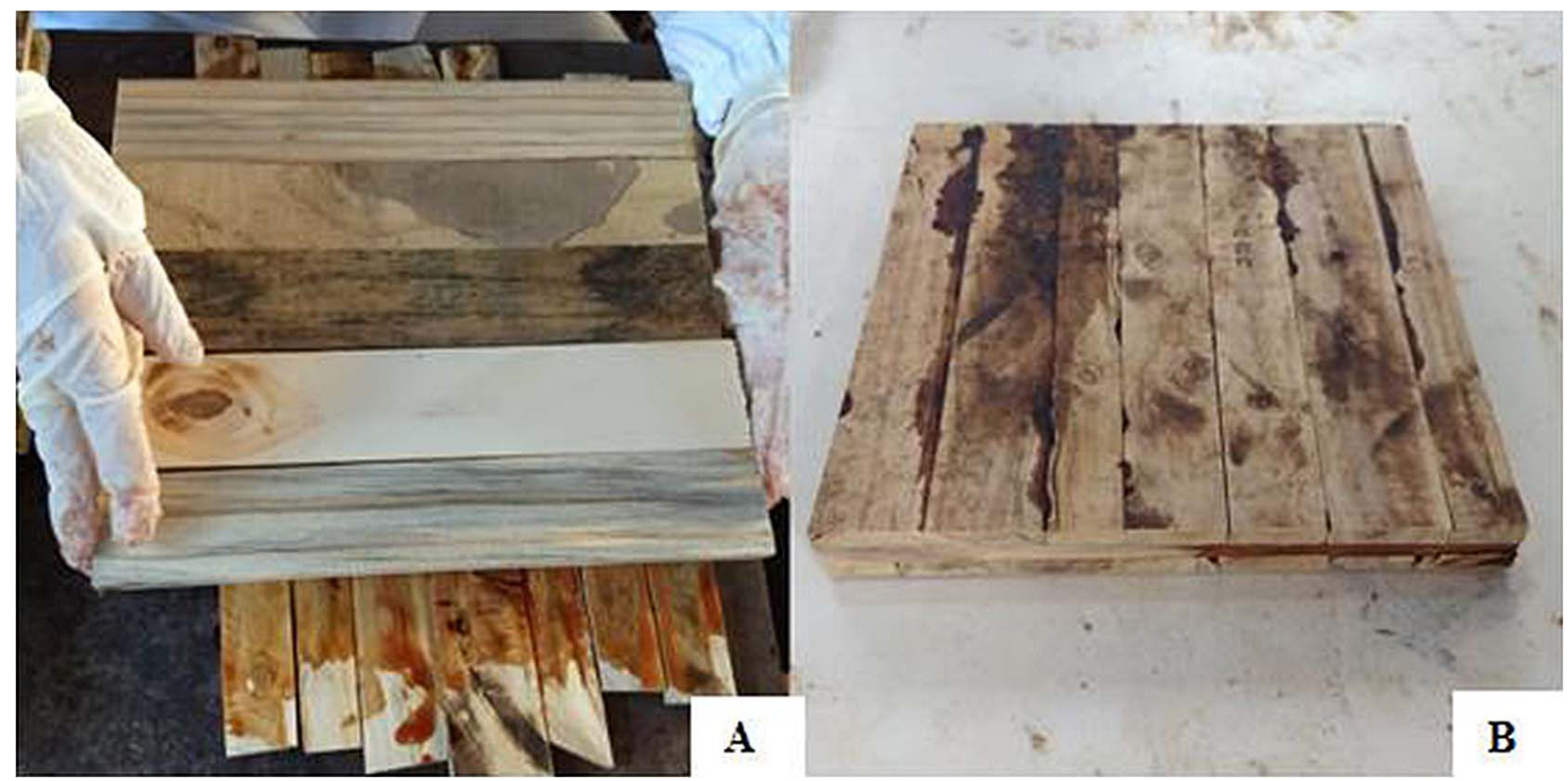

Figure 1: Manufacture of the CLT panel: $(A)$ bonding the veneer and $(B)$ finished panel. 


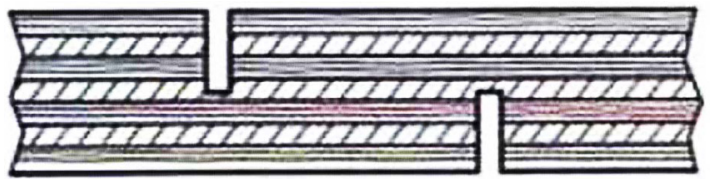

Figure 2: Specimen used in the shear test.

Source: NBR 12466-1 (ABNT, 2006).

We performed the delamination test based on the procedures by Lestari et al. (2015). Four samples per panel were taken, totaling 16 samples with dimensions of $0.25 \times 0.04 \times 0.03$ $\mathrm{m}$ (length $\mathrm{x}$ width $\mathrm{x}$ thickness).

The mechanical properties will be compared with The North American (ANSI/APA PRG 320) Standard for CLT.

\subsection{Analysis of acoustic and thermal perfor- mance}

For the evaluation of acoustic performance, the panels were subjected to the sound insulation test in the laboratory, for that purpose, the procedures of ISO 10140-5 (International Organization for Standardization - ISO, 2010) and ISO 717-1 (ISO, 2013) were followed to obtain the unique performance number. In the laboratory, environmental conditions are controlled, and parameters such as air humidity and temperature are measured, as they are used in calculating sound absorption in the reception environment and the Sound Reduction Index (R) as shown in Equation 3.

$\mathrm{R}=\mathrm{L} 1-\mathrm{L} 2+10 \log (\mathrm{S} / \mathrm{A})$

In which:

$\mathrm{L} 1=$ average level in the emission environment, in $\mathrm{dB}$;

$\mathrm{L} 2$ = average level in the reception environment, in $\mathrm{dB}$;

$\mathrm{S}=$ area of the specimen, in $\mathrm{m}^{2}$; and

$\mathrm{A}=$ sound absorption in the reception environment, in $\mathrm{m}^{2}$

The thermal performance analysis was verified, the importance of which is given by the thermal discomfort of wooden houses and is related to the low thermal inertia of the construction system. To determine the thermal conductivity of the coffee and pine panels, the method described by (Castro et al., 2019) was followed, using a chamber, composed of reconstituted wood panels and for sealing, polystyrene plates.

Using the Data Collector equipment, model IM DC 100-01E, from Yokogawa, the temperatures were recorded by the sensors and with this test it was possible to determine the thermal conductivity, through Equation 4.

$\lambda=((270 . \mathrm{e})) / \Delta \mathrm{T}$

In which:

$\lambda=$ thermal conductivity $\left(\mathrm{W} \cdot \mathrm{m}^{-1} \mathrm{C}^{-1}\right)$ $\mathrm{e}=$ panel thickness $(\mathrm{m})$

$\Delta \mathrm{T}=$ panel Temperature variation $\left({ }^{\circ} \mathrm{C}\right)$

\subsection{Experimental design and statistical analysis of the data}

The basic wood density and chemical composition of the particles were analyzed. We adopted a completely randomized design and for the production of the panels, four compositions were adopted for joining the veneer (treatments), as shown in Table 1.

Table 1: Experimental treatments performed.

\begin{tabular}{cc}
\hline Treatments & Composition (veneer) \\
\hline 1 & $100 \%$ Coffee \\
2 & $67 \%$ Coffee \\
3 & $33 \%$ Coffee \\
4 & $0 \%$ Coffee \\
\hline
\end{tabular}

Four panels were manufactured for each treatment, thus totaling 16 experimental units. For the panel tests, analysis of variance and $F$ tests $(p<0.05)$ were performed. In case of difference, the Scott-Knott test at $5 \%$ of significance was used to discriminate the means.

\section{RESULTS}

\subsection{Basic density of raw materials}

Figure 3 represents the basic density obtained for both evaluated materials.

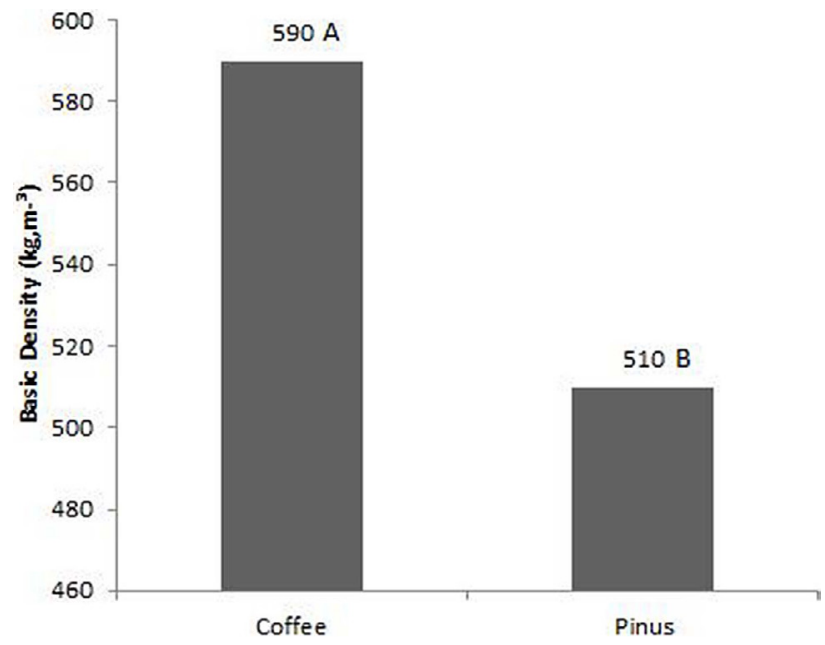

Figure 3: Basic density of pine and coffee wood.

The basic density obtained for the coffee wood waste was $590 \mathrm{~kg} \cdot \mathrm{m}^{-3}$, and for the pinus was $510 \mathrm{~kg} \cdot \mathrm{m}^{-3}$. 


\subsection{Chemical analysis of the woods}

The mean values shown in Table 2 refer to the levels of holocellulose, lignin, ash and extractives of both materials evaluated.

The average holocellulose content obtained for pine wood was significantly higher in relation to coffee wood. On the other hand, coffee wood showed higher levels of extractives and ash. There was statistical equality only for the lignin content.

\subsection{Physical properties}

The mean values of apparent density (AD), moisture content (MC), water absorption, after 2 hours (WA2h) and 24 hours (WA24h) of immersion of the panels are described in Table 3.

The mean values obtained for apparent density and moisture content did not show significant differences between treatments. For water absorption in 2 and $24 \mathrm{~h}$, there was a difference between treatments. The panels of treatment 4 , that is, those made of pine wood, showed the highest water absorption rates.

\subsection{Mechanical properties}

The mean values of modulus of rupture (MOR) and modulus of elasticity (MOE) for static bending, shear strength (ST) and delamination (D), for each treatment. According to the data described in Table 4, it is observed that the panels made up only of pine veneer showed better performance for MOR and MOE and differed significantly from the others.

In relation to the MOE, it is noted that the panels composed with varied veneer, did not differ between themselves and the panels constituted only with veneer of waste coffee wood, reached the lowest mean value, differing from the other treatments. Regarding MOR, it is observed that all treatments differed statistically from each other. The panels made only of pine wood showed a higher mean value, differing from the other treatments.

To assess the quality of the glue line of the panels, shear tests were carried out, with the orientation parallel to the fibers. According to Table 4, it is observed that the panels of Treatments 1 and 3 were statistically equivalent to each other. The treatment 2 panels showed the best performance, differing significantly from the treatment 4 panels. In relation to delamination, it is noted that the panels of treatment 2 showed a superior value $(58.55 \%)$ in relation to the panels of treatment 3 (47.5), both constituted with mixed veneer.

\subsection{Acoustic analysis and thermal conductivity}

Figure 4 represents the behavior of the panels produced, in relation to sound insulation.

Table 2: Chemical characterization of pine and coffee wood particles.

\begin{tabular}{ccccc}
\hline Woods & Holocellulose (\%) & Lignin (\%) & Total extractives (\%) & Ashes (\%) \\
\hline Pinus & $70.76(2.0) \mathrm{a}$ & $29.20(2.6) \mathrm{a}$ & $7.38(0.49) \mathrm{b}$ & $0.26(0.01) \mathrm{b}$ \\
Coffee & $50.67(2.52) \mathrm{b}$ & $28.49(2.12) \mathrm{a}$ & $15.30(4.03) \mathrm{a}$ & $3.78(0.69) \mathrm{a}$ \\
\hline
\end{tabular}

Mean values followed by the same letter, in the column, do not differ statistically by the Scott-Knott mean test, at $5 \%$ significance. Values in parentheses represent the standard deviation.

Table 3: Mean values of apparent density (AD), moisture content (MC), water absorption in $h(W A 2 h)$ and $24 h$ (WA24h) of the panels.

\begin{tabular}{ccccc}
\hline Treatments & AD $\left(\mathrm{kg} . \mathrm{m}^{-3}\right)$ & MC $(\%)$ & WA 2h (\%) & WA 24h $(\%)$ \\
\hline $100 \%$ coffee & $630(0.03) \mathrm{a}$ & $10.4(0.21) \mathrm{a}$ & $10.2(0.68) \mathrm{d}$ & $33.3(5.10) \mathrm{d}$ \\
$67 \%$ coffee & $650(0.03) \mathrm{a}$ & $11.2(0.15) \mathrm{a}$ & $19.2(1.92) \mathrm{c}$ & $40.6(2.38) \mathrm{c}$ \\
$33 \%$ coffee & $650(0.03) \mathrm{a}$ & $11.7(0.12) \mathrm{a}$ & $37.7(4.03) \mathrm{b}$ & $56.2(5.00) \mathrm{b}$ \\
$0 \%$ coffee & $660(0.02) \mathrm{a}$ & $10.5(0.36) \mathrm{a}$ & $46.9(5.83) \mathrm{a}$ & $72.5(6.20) \mathrm{a}$ \\
\hline
\end{tabular}

Mean values followed by the same letter, in the column, do not differ statistically by the Scott-Knott mean test, at $5 \%$ significance. Values in parentheses represent standard deviation.

Table 4: Mean values obtained for the modulus of elasticity (MOE), modulus of rupture (MOR), shear strength (ST), and delamination $(D)$ of the panels produced with waste wood veneer of coffee and pine.

\begin{tabular}{ccccc}
\hline Treatments & MOE $\left(\mathrm{N} \cdot \mathrm{m}^{-2}\right)$ & MOR $\left(\mathrm{N} \cdot \mathrm{m}^{-2}\right)$ & $\mathrm{ST}\left(\mathrm{N} \cdot \mathrm{m}^{-2}\right)$ & $\mathrm{D}(\%)$ \\
\hline $100 \%$ coffee & $1.62 \times 10^{7}(651.09) \mathrm{c}$ & $1.12 \times 10^{8}(1.79) \mathrm{b}$ & $2.09 \times 10^{6}(0.07) \mathrm{c}$ & Not present \\
$67 \%$ coffee & $2.19 \times 10^{7}(757.49) \mathrm{b}$ & $9.3 \times 10^{7}(1.39) \mathrm{d}$ & $2.85 \times 10^{6}(0.02) \mathrm{a}$ & $58.5(3.56) \mathrm{a}$ \\
$33 \%$ coffee & $2.19 \times 10^{7}(452.14) \mathrm{b}$ & $1.04 \times 10^{8}(2.81) \mathrm{c}$ & $2.15 \times 10^{6}(0.08) \mathrm{c}$ & $47.5(4.98) \mathrm{b}$ \\
$0 \%$ coffee & $2.41 \times 10^{7}(770.91) \mathrm{a}$ & $1.35 \times 10^{8}(2.51) \mathrm{a}$ & $2.45 \times 10^{6}(0.02) \mathrm{b}$ & Not present \\
\hline
\end{tabular}

Mean values followed by the same letter, in the column, do not differ statistically by the Scott-knott mean test, at $5 \%$ significance. Values in parentheses represent standard deviation. 


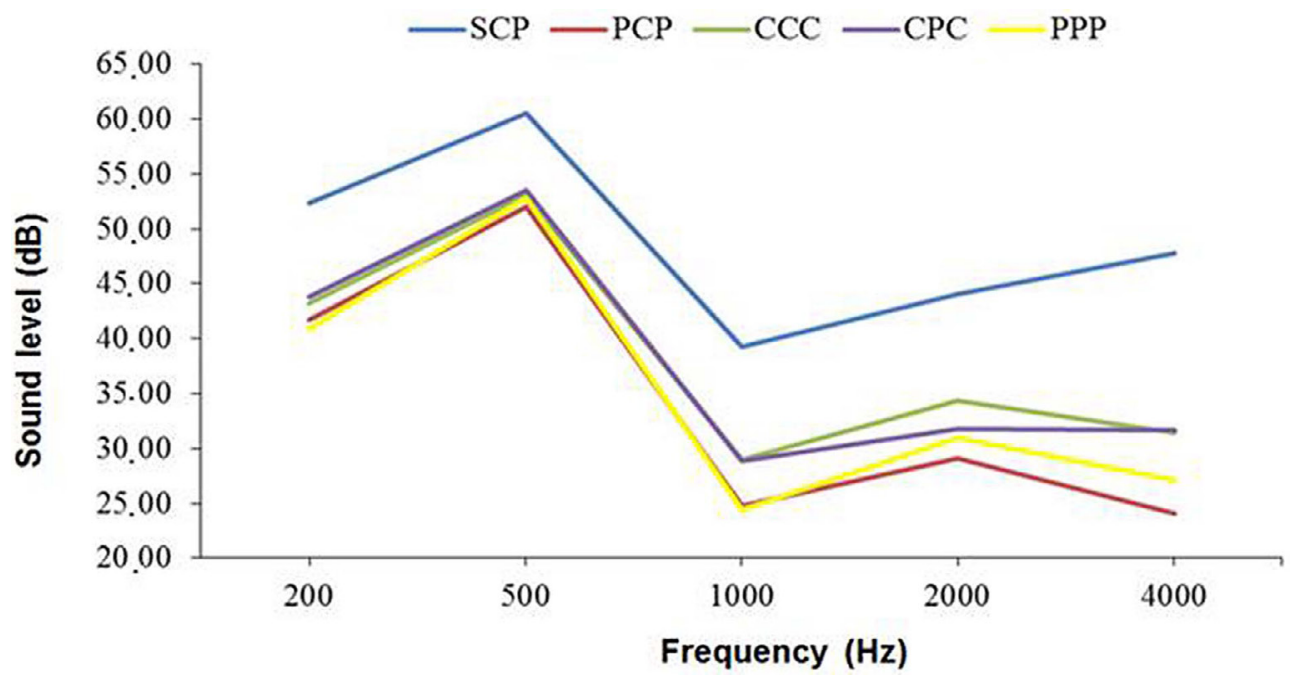

Figure 4: Graph of the mean values of acoustic insulation for the CLT panels; SCP: without specimen; CCC: $100 \%$ coffee; CPC: $67 \%$ coffee; PCP: $33 \%$ coffee; PPP: $0 \%$ coffee.

Table 5 shows the mean values obtained by the panels in relation to thermal insulation.

Table 5: Mean values of thermal conductivity of panels produced with waste wood veneer of coffee and pine.

\begin{tabular}{cc}
\hline Treatments & Conductivity $\lambda\left(\mathrm{W} \cdot \mathrm{m}^{-1} \cdot{ }^{\circ} \mathrm{C}^{-1}\right)$ \\
\hline $100 \%$ coffee & $0.31(0.09) \mathrm{a}$ \\
$67 \%$ coffee & $0.30(0.04) \mathrm{a}$ \\
$33 \%$ coffee & $0.26(0.02) \mathrm{a}$ \\
$0 \%$ coffee & $0.34(0.01) \mathrm{a}$ \\
\hline
\end{tabular}

Mean values followed by the same letter, in the column, do not differ statistically by the Scott-knott mean test, at $5 \%$ significance. Values in parentheses represent the standard deviation.

\section{DISCUSSION}

\subsection{Basic density of raw materials}

As shown in Figure 3, it can be observed that the basic density obtained for pine wood was significantly lower, in relation to the density of coffee wood (Figure 3). The North American standard of CLT with performance classification suggests long fiber species with a minimum density gravity of $0.35 \mathrm{~g} . \mathrm{cm}^{-3}$ for manufacturing CLT (ANSI / APA PRG 320 2018). By adopting only this value as a reference, both species meet the requirement.

Based on the obtained value, pine wood can be classified as a low density wood (Figure 3), based on the classification by Coradin et al. (2010) and Silveira, Rezende and Vale (2013), who stipulated values between 550 and 720 $\mathrm{kg} \cdot \mathrm{m}^{-3}$ for this class. The value obtaine $\mathrm{d}$ in this experiment was lower than the result obtained by Matos et al. (2019), who reported $530 \mathrm{~kg} \cdot \mathrm{m}^{-3}$, for the same species at 18 years of age.
On the other hand, it was higher than the mean values reported by Trianoski et al. (2013), who evaluated seven species of tropical pine, among them P. oocarpa and used five sampling points along the stem, thus obtaining $480 \mathrm{~kg} \cdot \mathrm{m}^{-3}$. Pinati et al. (2018) found a mean value of $470 \mathrm{~kg} \cdot \mathrm{m}^{-3}$ and Mendes et al. (2014) obtained a similar value $\left(500 \mathrm{~kg} \cdot \mathrm{m}^{-3}\right)$ to that obtained in this study.

The basic density obtained for the coffee wood waste was $590 \mathrm{~kg} . \mathrm{m}^{-3}$, being, therefore, classified as a medium density wood, according to Coradin et al. (2010) and Silveira, Rezende and Vale (2013). The result obtained was close to that obtained by Pereira et al. (2014) who obtained $600 \mathrm{~kg} \cdot \mathrm{m}^{-3}$.

\subsection{Chemical analysis of the woods}

According to the values described in Table 2, it is observed that the mean values for the chemical components differed statistically from each other, with the exception of the lignin content. The average holocellulose content obtained for pine wood corresponded to $70.76 \%$, being in the range stipulated by Modes et al. (2019), which establishes a variation between 50 and $85 \%$ for holocellulose in pine species.

The values obtained in the study fluctuated in relation to the values reported in the literature. Pinati et al. (2018) obtained an average content of $69.63 \%$ of holocellulose for Pinusoocarpa wood, a value similar to that found in this study. Leite et al. (2014), when evaluating the chemical composition of coffee wood found an average content of $57.91 \%$, higher than that obtained in this study.

The results obtained for the lignin content fluctuated in relation to the values found in the literature. Vivian et al. (2015), studying the Pinus taeda wood, obtained an average content of $26.71 \%$, Leite et al. (2014), when checking the lignin content in coffee $\mathrm{w}$ ood o b tained $32.35 \%$. Lignin 
is a natural and renewable organic compo und, which has properties that can contribute to the adhesion process (Ang et al., 2019), it is noteworthy that its structure is similar to phenol-based adhesives (Qiao et al., 2015). The quantification of lignin is important for CLT panels, as it is related to mechanical properties, such as rigidity and toughness, which are fundamental for structural composites.

Regarding the average levels of total ex $t$ ractives, it is observed that the result obtained for pine wood was lower than the result found by Zanuncio et al. (2014), who reported $10.91 \%$. For coffee wood, the value obtained was higher than that reported by Pereira et al. (2014) who found $6.1 \%$. The high content of these components can considerably reduce the resistance to internal adhesion, characterizing a low performance glue line, reducing the quality and the final performance of the panels (Fonte; Trianoski, 2015).

For ash contents, Matos et al. (2019) obtained a content of $0.15 \%$ for Pinus wood, lower than that obtained in this study. Pereira et al. (2014) obtained $0.68 \%$ for coffee wood. High concentrations of this component can block reactive sites for adhesion, affecting the quality of the bonding and the mechanical performance of the panel (Soares et al., 2017).

\subsection{Physical properties}

In relation to physical properties it was observed that there was no statistical difference between the panels, for the apparent density (Table 3 ). The mean values obtained for the panels in all treatments were exceeding the results reported in the literature.

Baño et al. (2018) studied CLT panels made of Pinus Loblolly wood and polyurethane adhesive. The dimensions of the panels were $0.381 \times 0.102 \mathrm{~m}$, similar to the panels of this study and the mean value obtained for density was $388 \mathrm{~kg} . \mathrm{m}^{-3}$. Compared to the treatment consisting only of pine veneer, in this study, a difference of $270 \mathrm{~kg} \cdot \mathrm{m}^{-3}$ is observed.

Birinci et al.(2020) analyzed the structural performance of CLT panels produced with Pinus sylvestris and Picea orientalis. The panels had dimensions of $0.24 \mathrm{~m} \times 0.24 \mathrm{~m} \times$ $0.15 \mathrm{~m}$ (length $\mathrm{x}$ width $\mathrm{x}$ thickness) and were produced with polyurethane adhesive with a spread rate of $0.160 \mathrm{~kg} . \mathrm{m}^{-2}$. In relation to the apparent density, the authors obtained mean values of $470 \mathrm{~kg} . \mathrm{m}^{-3}$ for the Pinus sylvestris CLT and 460 $\mathrm{kg} \cdot \mathrm{m}^{-3}$ for the Picea orientalis CLT. The differences may be due to the type of adhesive, conditions of pressing and age of the wood used.

According to ANSI/APA PRG 320 (2012), CLT panels should be used in moisture-free conditions, as in most covered structures, where the average lumber moisture content is less than $16 \%$.It should be noted that this standard, being international, was carried out based on the climatic conditions of the USA. In Brazil, the NBR 7190 (ABNT, 1997), stipulates $12 \%$ moisture content. According to the values obtained for the moisture content of the panels (Table 3) it appears that all are within the standards stipulated by both standard rules.

Regarding the moisture, it is noted that the different combinations of veneer did not interfere in this property, indicating homogeneous drying of the veneer. Probably the high temperatures used during the drying of the veneer and hot pressing of the panels, reduced their sorption capacity, and, consequently, reduced the equilibrium humidity. This fact corroborates with Skaar (1988), when affirming that the elevation of the temperature in the wood results in the reduction of the equilibrium humidity to a considered relative humidity and a permanent reduction in the hygroscopicity. In addition, the packaging of the panels in an air-conditioned room may have contributed to equalizing the moisture content of the panels. Similar values of moisture content were observed by Pinati et al. (2018), when studying Pinus oocarpa blockboard plywood panels. The moisture content found in this work was compatible with the values presented in the research cited.

Regarding water absorption in 2 and 24 hours, it is observed that all treatments differed from each other (Table 3 ). Regarding WA2h, the panels produced only with coffee wood waste showed mean values corresponding to 10.2 and $33.3 \%$, for water absorption in 2 and 24 hours, respectively. It is noted that the inclusion of a pine blade in the constitution of the panels caused an increase that corresponds to practically twice the water absorption rate in relation to the treatment 1 panels. With the inclusion of two pine blades in the panels (treatment 3 ) the increase is equivalent to 3.69 times greater in the absorption rate and in panels produced only with pine blades, the absorption becomes approximately five times greater, in relation to the coffee panels. The same trends are observed for WA24h.

In part, this result can be explained by the chemical nature of the coffee wo od, as seen in Table 2, as it has a higher content of extra $\mathrm{c}$ ts than the pine wood, which can result in less contraction and swelling of the pots, as the Hydrophobic extractives prevent water absorption, due to the lack of chemical affinity with water (Sheshmani, 2013; Kim et al., 2008). In addition, the basic density of coffee wood was higher than that of pine (see item 3.1). The greater the specific mass, the lower the water content that the wood can contain in saturation (Tsoumis, 1991). This may be associated with the more closed anatomical structural arrangement of the coffee wood, which, because it is more dense, promoted an initial barrier to the entry of water, caused by the reduction of empty spaces (lumen, ve ssels and intercellular spaces). Pine wood has a large amount of tracheids, which are hollow anatomical structures, responsible for conducting the wood and facilitating the process of absorption, drying and wood preservation treatments (Burger; Richter, 1991).

The low WA values of panels made from coffee waste, in relation to pine panels, can be seen as a positive point, since an alternative material is being suggested, of low cost 
as a source of raw material for production of the panels. The results obtained for the pine panels were superior to the results obtained by Souza et al. (2011) who evaluated parallel veneer panels (LVL) made with Pinus oocarpa and obtained average results of WA2h and WA24h corresponding to $12.5 \%$ and $24.4 \%$, respectively. Lima et al. (2013) obtained $85.6 \%$ for total water absorption, therefore, higher than the result obtained in this study.

\subsection{Mechanical properties}

The panels made of coffee veneer showed the lowest results determined at $1,62 \times 10^{7} \mathrm{~N} . \mathrm{m}^{-2}$ and $1,12 \times 10^{8} \mathrm{~N} . \mathrm{m}^{-2}$ for the MOE and MOR, respectively (Table 4). It is noted that from the moment the inclusion of pine blades in the panels occurs, the rigidity increases, significantly improving this property. In the treatment consisting only of pine blades, the increment corresponds to $67.22 \%$, in relation to the coffee wood panels.

Still according to table 4 , it is observed that the lowest values were obtained for panels laminated with mixed blades, however the MOR of the panels made only with pine blades followed the same trend as the MOE, since these showed the highest value $\left(1,35 \times 10^{8} \mathrm{~N} \cdot \mathrm{m}^{-2}\right)$ for the resistance of the panels. The improvement observed for pine panels was $83 \%$ in relation to panels produced only with veneer of coffee wood. We assume that the higher values obtained for the MOE and MOR of pine laminated panels are due to the anatomical arrangement of the wood, as it has long fibers (tracheids) and is more resistant to bending. The panels produced and evaluated showed higher values than the results reported in the literature.

Ecker, Mi otto and Turmina (2017) evaluat ed CLT panels formed by three orthogonal layers of pine veneer, joined with mono-component polyurethane adhesive. The following spread rate was used: $0.12 \mathrm{~kg} \cdot \mathrm{m}^{-2}, 0.16 \mathrm{~kg} . \mathrm{m}^{-2}$ and $0.2 \mathrm{~kg} . \mathrm{m}^{-2}$, for comparison, panels with a spread rate of $0.2 \mathrm{~kg} \cdot \mathrm{m}^{-2}$ will be considered. The veneer had an average thickness of $0.0215 \mathrm{~m}$, widths between $0.09 \mathrm{~m}$ and $0.11 \mathrm{~m}$ and lengths between $3 \mathrm{~m}$ and 3,2 m. After assembly, the panels were pressed in a hydraulic press with a vertical pressure of $1.2 \times 10^{6} \mathrm{~N} . \mathrm{m}^{-2}$, for 4 hours cold. For panels bonded with $0.2 \mathrm{~kg} . \mathrm{m}^{-2}$, the researchers obtained mean values of $3.421 \times 10^{7} \mathrm{~N} . \mathrm{m}^{-2}$ for MOR and 10,200.04 for MOE. It is emphasized that although the MOE and MOR values of this research are higher, it must be taken into account that the proportion of amplitude used was different. We used a range of $8.33 * \mathrm{~h}$ and the authors used $46 * \mathrm{~h}$ ".

Barreto et al. (2019) e valuated the performance of hybrid panels (CLT) in construction systems and used Pinus spp wood. and bamboo (Dendrocalamusgiganteus) for panel production. They used melamine-urea-formaldehyde (MUF) adhesive to glue the laminates in a three-layer configuration, with a transversal orientation: two outer layers of bamboo and a central layer of pine wood. The authors obtained values of $1.331 \times 10^{10} \mathrm{~N} . \mathrm{m}^{-2}$ and $6.5 \times 10^{4} \mathrm{~N} . \mathrm{m}^{-2}$, for the MOE and MOR, respectively. It is noted that the hybrid panels of this study obtained superior resistance to the panels in the literature.

Comparing the panels, it is observed that those made with coffee and pine blades show a MOR higher than $60 \%$ in relation to the values mentioned, for the average MOR, the increase corresponds to a gain in resistance of $65 \%$. However, it is noteworthy that the different production conditions of the panels, type, age of the material and adhesive, influence the results.

Alencar and Moura (2019) evaluated CLT hybrid panels with three layers and different combinations of pine and eucalyptus veneer and obtained a MOR of $3.92 \times 10^{7}$ N.m 2 and MOE of $7,24 \times 10^{9} \mathrm{~N} \cdot \mathrm{m}^{-2}$. The aforementioned authors obtained lower values in relation to this research, proving the efficiency of the CLT panels produced with pine and waste coffee wood. As previously mentioned, although the values of MOE and MOR in this research are higher, it should be taken into account that the proportion of amplitude used was different in both studies.

According to a certification issued to the company KLH Massive Holz GmbH, Austrian company that created the CLT (Cross Laminated Timber) by EOTA (European Organization for Technical Evaluation), in which it specifies for the CLT panels values $1.2 \times 10^{10} \mathrm{~N} \cdot \mathrm{m}^{-2}$ for the MOE and $2,4 \times 10^{7} \mathrm{~N} \cdot \mathrm{m}^{-2}$ for the MOR, the panels fit into the requirements. All panels meet the requirement of ANSI/APA PRG 320 (2012), which stipulates average values of $8.3 \times 10^{9} \mathrm{~N} . \mathrm{m}^{-2}$ and $1 \times 10^{7} \mathrm{~N} . \mathrm{m}^{-2}$ for MOE and MOR, respectively.

According to table 4, the panels made up of veneer of coffee, or at least one blade of coffee wood, presented the lowest averages of shear strength. In part, this can be explained by the fact that the waste coffee wood has higher quantities of extractives (Table 2). The type and quantity of extractives can negatively influence the adhesion of the wood surface, as they are the main responsible for the inactivation of the surface (wetting of the adhesive) and can also change the surface $\mathrm{pH}$ of the wood (Albino; Mendes; Mendes, 2012).

The results obtained in this research fluctuated with the results available in the literature. Ecker, Miotto and Turmina (2017), found for CLT made up of $0.2 \mathrm{~kg} \cdot \mathrm{m}^{-2}$ mono-component polyure thane adhesive, an average shear bond strength of $8.42 \times 10^{6} \mathrm{~N} . \mathrm{m}^{-2}$; in the parallel direction and $3.02 \times 10^{6} \mathrm{~N} . \mathrm{m}^{-2}$ in the normal direction. Navaratnam et al. (2020) studied CLT panels made with Pinus radiata wood blades and evaluated the performance of the panels in relation to shearing. The panels had three layers, with dimensions of $1.26 \mathrm{~m} \mathrm{x} 0.52 \mathrm{x}$ $0.106 \mathrm{~m}$ (length $\mathrm{x}$ width $\mathrm{x}$ thickness) and used polyurethane adhesive. The had a mean value of $2 \times 10^{6} \mathrm{~N} \cdot \mathrm{m}^{-2}$, a result close to the one obtained in treatment 1 , for panels made only with coffee waste wood. The requirement of ANSI/APA PRG 320 (2012) stipulates a minimum value for shear of $1.3 \times 10^{6}$ N.mtherefore all panels met the requirement. 
Still a ccording to Table 4 , it is observed that there was no delamination of the panels constituted with veneer of the same species (treatment 1 and 4), that is, there were no changes that could compromise the structure of the woodadhesive interface, thus demonstrating better performance. On the other hand, the panels of treatments 2 and 3 had a failure in the quality of bonding of the veneer, referring to 58.5 and $47.5 \%$ respectively. It is assumed that the veneer had different degrees of anisotropy, which is why it resulted in delamination.

Segundinho et al. (2015) evaluated the shear strength in the cross laminated timber (CLT) glue line manufactured with three wood species, among them Pinusoocarpa. The veneer were bonded with bicomponent adhesive based on melamineurea-formaldehyde (MUF) and the spread rate used were 0.2 $0.25 \mathrm{~kg} \cdot \mathrm{m}^{-2}$ (double glue line) and a minimum bonding pressure of $1 \times 10^{6} \mathrm{~N} . \mathrm{m}^{-2}$. The authors also did not observe delamination on the veneer of the CLT formed with Pinus.

According to ANSI/AP A PRG 320 (2012) for the product to be qualified, this document requires less than $5 \%$ of delamination in all samples. The panels made with the same veneer presented satisfactory performance.

\subsection{Acoustic analysis and thermal conductivity}

The sound insulation of the panels was measured and reproduced in figure 4 and according to the designations of NBR 10152 (ABNT, 2020), in relation to the frequency of 200 $\mathrm{Hz}$, all panels evaluated were considered acceptable, for sound comfort in the range of 40 to $50 \mathrm{~dB}$, such as the living room. For $500 \mathrm{~Hz}$, all panels fall into the hospital services area, which serve a range of $45-55 \mathrm{~dB}$. For 1000 to $4000 \mathrm{~Hz}$ only the CCC and CPC panels fall within the range of 30-40 dB and for 2000 $\mathrm{Hz}$ the CCC, CPC and PPP panels stand out and can be used in places such as theaters, concert halls and meeting rooms.

In gene ral, it is concluded that the woody wastes of coffee wood, associated or not with pine wood, have the potential to produce panels of the CLT type, since the results obtaine $\mathrm{d}$ were in ac cordance with the standards used, and therefore, they can be recommended to be used as parts of construction systems, and can be used as sealing panels for thermal and acoustic insulation.

Regardi ng thermal c onductivity, no significant differe nces were fo und between the panels, so they all showed similar beha vior, regardless of the composition of the veneer (Table 5). The values obtained are in accordance with the requirements of NBR 15220 (ABNT, 2005), which recommends a value less than $2 \mathrm{~W} \cdot \mathrm{m}^{-1} \cdot{ }^{\circ} \mathrm{C}^{-1}$ so that the panel can have a thermal insulating char a cteristic. The results obtained in this research corroborate Asdrubali et al. (2017) and Jayalath et al (2020) when stating that panels of the CLT type have a satisfa ctory value for thermal conductivity, in relation to other materials traditionally used in construction. Examples include cement, masonry brick and gravel concrete, which have a thermal conductivity of $0.90 ; 0.60$ to 0.70 and $2.0 \mathrm{~W} \cdot \mathrm{m}^{-1} \cdot{ }^{\circ} \mathrm{C}^{-1}$ respe ctively (Labora t ory of thermophysical properties and prototyping, 2020).

\section{CONCLUSIONS}

The study verified the potential of using coffee waste wood as a raw material for the production of CLT, isolated and associated with Pinus oocarpa wood and the following conclusions were obtained: Regarding MOR and MOE, all panels met the requirements of KLH Massive Holz GmbH, an Austrian company that created the CLT (Cross Laminated Timber) and ANSI/APA PRG 320 (2012); Regarding shear strength, all panels met the requirements of ANSI/APA PRG 320 (2012). For delamination, the panels produced only with pine veneer or coffee veneer did not delaminate, according to the requirements of ANSI/APA PRG 320 (2012).

Regarding acoustics and thermal conductivity, all panels met the minimum requirements indicated in the standards NBR 10152 (ABNT, 2020) and NBR 15220 (ABNT, $2005)$, respectively. In relation to the mechanical properties (MOR, MOE e ST), all combinations passed all of the standard qualification criteria required for structural CLT.

\section{ACKNOWLEDGEMENTS}

We would like to thank the Coordination for the Improvement of Higher Education Persons (CAPES), Foundation for Research Support of the State of Minas Gerais (FAPEMIG), National Council for Scientific and Technological Development (CNPq), the Graduate Program in Biomaterials Engineering (PPG BIOMAT-UFLA).

\section{REFERENCES}

ALBINO, V. C. S.; MORI, F. A.; MENDES, L. M. Influência das características anatômicas e do teor de extrativos totais da madeira de Eucalyptus grandis W. Hill ex Maiden na qualidade da colagem. Ciência Florestal, 22(4):803-811, 2012.

ALENCAR, J.; MOURA, J. D. Mechanical behavior of cross laminated timber panels made of low added value timber. Forest Products Journal, 69(3):177-184, 2019.

\section{AMERICAN NATIONAL STANDARD, ANSI/APA PRG} 320: Standard for Performance-Rated Cross-Laminated Timber, APA - The Engineered Wood Association, Tacoma, Washington, U.S.A. 2012. Available in: $<$ https:// www.structurlam.com/wp-content/uploads/2016/10/ PRG_320-2012-Standard-for-CLT.pdf>. Access in: February, 27, 2021. 
ANG, A. F. et al. Lignin-based copolymer adhesives for composite wood panels - A review. International Journal of Adhesion and Adhesives, 95:102408, 2019.

ASDRUBALI, F. et al. A review of structural, thermophysical, acoustical, and environmental properties of wooden materials for building applications. Building and Environment, 114: 307-332, 2017.

\section{ASSOCIAÇÃO BRASILEIRA DE NORMAS TÉCNICAS} - ABNT. NBR 10152: Níveis de pressão sonora em ambientes internos a edificações. Rio de Janeiro: ABNT, 2020. 21p.

ASSOCIAÇÃO BRASILEIRA DE NORMAS TÉCNICAS ABNT. NBR 11941: Madeira: determinação da densidade básica. Rio de Janeiro: ABNT, 2003. 6p.

\section{ASSOCIAÇÃO BRASILEIRA DE NORMAS TÉCNICAS} - ABNT. NBR 13999: Papel, cartão, pastas celulósicas e madeira - Determinação do resíduo (cinza) após a incineração a $525^{\circ}$. Rio de Janeiro: ABNT, 2017. 4p.

ASSOCIAÇÃO BRASILEIRA DE NORMAS TÉCNICAS ABNT. NBR 14583: Madeira - determinação do material solúvel em etanol-tolueno e em diclorometano e em acetona. Rio de Janeiro: ABNT, 2010a. 3p.

ASSOCIAÇÃO BRASILEIRA DE NORMAS TÉCNICAS ABNT. NBR 15220: Desempenho térmico de edificações, parte 3: Zoneamento bioclimático brasileiro e diretrizes construtivas para habitações unifamiliares de interesse social. Rio de Janeiro: ABNT, 2005. 30 .

ASSOCIAÇÃO BRASILEIRA DE NORMAS TÉCNICAS ABNT. NBR 7190: Projeto de estruturas de madeira. Rio de Janeiro: ABNT, 1997. 107p.

\section{ASSOCIAÇÃO BRASILEIRA DE NORMAS TÉCNICAS}

- ABNT. NBR 7989: Pasta celulósica e madeira Determinação de lignina insolúvel em ácido. Rio de Janeiro: ABNT, 2010b. 6p.

\section{ASSOCIAÇÃO BRASILEIRA DE NORMAS TÉCNICAS} - ABNT. NBR 9486: Compensado: determinação de absorção de água. Rio de Janeiro: ABNT, 2011. 2p.

\section{ASSOCIAÇÃO BRASILEIRA DE NORMAS TÉCNICAS}

- ABNT. NBR 9535: Compensado- Determinação do inchamento - Método de ensaio. Rio de Janeiro, ABNT, 2012. 3p

\section{ASSOCIAÇÃO BRASILEIRA DE NORMAS TÉCNICAS}

- ABNT. NBR ISO 12466-1: Madeira compensada -

Qualidade de colagem Parte 1: Métodos de ensaio. Rio de Janeiro, ABNT, 2006.16p.
BAÑO, V. et al. Characterization and structural performance in bending of CLT panels made from small-diameter logs of loblolly/slash pine. Materials, 11(12):2436, 2018.

BARRETO, M. et al. Structural performance analysis of cross-laminated timber-bamboo. BioResources, 14(3):5045-5058, 2019.

BERNI, M. D.; MANDUCA, P. C. Oportunidades da valorização de resíduos sólidos da colheita, processamento e torrefação do grão de café no brasil. In: HOLZMANN, H. A.; DALLAMUTA, J. (org). Resultados das pesquisas e inovações na área das engenharias 2. Ponta Grossa, PR: Atena, p. 8-21, 2020.

BETETTE, B. S. S.; CASTILHO, L. B. Uso de cross laminated timber (CLT) em projetos estruturais. Revista Artigos.Com, 7:e2751, 2019.

BIRINCI, A. et al. Structural performance analysis of cross laminated timber (CLT) Produced from pine and spruce grown in Turkey. Journal of Anatolian Environmental and Animal Sciences, 5(5):819-824, 2020.

BOWYER, J. S. et al. Modern tall wood buildings: Opportunities for innovation. 2016. Minneapolis, MN. Available in: $<$ http://www.adivbois.org/wp-content/uploads/ Int_0_Com_Rex_Modern-Tall-Wood-BuidlingsOpportunitesfor-innovation.pdf $>$. Access in: February, 27, 2021.

BURGER, L. M.; RICHTER, H. G. Anatomia da madeira. São Paulo: Nobel, 1991. 154p.

CALIL NETO, C. et al. Specie - treatment - adhesive combinations for glulam purpose. Revista de Engenharia Civil IMED, 3(2):16-23, 2016.

CASTRO, E. D. et al. Analysis of the coffee peel application over the soil-cement bricks properties. Coffee Science, 14(1):12-23, 2019.

COMPANHIA NACIONAL DE ABASTECIMENTO CONAB. Acompanhamento da safra Brasileira de Café. 2020. Brasília, DF. Available in: <http://www. conab.gov.br> Access in: March, 03, 2021.

CORADIN, V. T. R. et al. Madeiras comerciais do Brasil: Chave interativa de identificação baseada em caracteres gerais e macroscópicos. Serviço Florestal Brasileiro, Laboratório de Produtos Florestais, 2010. CD-ROM. Available in: $<$ https://lpf.florestal.gov.br/pt-br/chaveinterativa-de-identificacao> Access in: March, 03, 2021.

ECKER, T. W. P.; MIOTTO, J. L.; TURMINA, G. Painéis de madeira laminada colada cruzada para lajes: avaliação experimental mecânica sob diferentes níveis de consumo de adesivo. Ciência \& Engenharia, 26(1):17-25, 2017. 
FRANÇA, M. E.; BOGO, A. J. Avaliação de conforto ambiental comparativa em edificações construídas em madeira laminada colada cruzada (Painéis CLT) e em sistemas construtivos tradicionais. Labor $\mathbf{E}$ Engenho, 13:e019016, 2019.

FONTE, A. P.; TRIANOSKI, R. Effect of grammage on the bonding quality of glue side of Tectona grandis wood. Revista de Ciências Agroveterinárias, 14(3):224-233, 2015.

HE, M.; SU, X.; LI, Z. Bending and compressive properties of cross-laminated timber (CLT) panels made from Canadian hemlock. Construction and Building Materials, 185:175-183, 2018.

\section{INTERNATIONAL ORGANIZATION FOR} STANDARDIZATION - ISO. ISO 10140-5: acoustics: Laboratory measurement of sound insulation of building elements: part 5: requirements for test facilities and equipment. Geneva, 2010. 35p.

\section{INTERNATIONAL ORGANIZATION FOR} STANDARDIZATION - ISO. ISO 717-1: Acoustics- Rating of sound insulation in building and building elements. Part 1: Airborne sound insulation, Geneva, 2013. 19p.

IWAKIRI, S. Painéis de madeira reconstituída. Curitiba: FUPEF, 2005. 247p.

IWAKIRI, V. T. et al. Production of structural particleboard of Mimosa scabrella benth with lignin phenol-formaldehyde resin. Floresta e Ambiente, 26(3):e20171006, 2019.

JAYALATH, A. et al. Life cycle performance of cross laminated timber mid-rise residential buildings in Australia. Energy and Buildings, 223:110091, 2020.

KIM, M. et al. Variation in wood properties of six natural acacia hybrid clones in northern Vietnam. Journal of Wood Science, 54(6):436-442, 2008.

LEITE, E. R. S. et al. Avaliação da qualidade da madeira de Coffea arabica L. como fonte de bioenergia. Cerne, 20(4):541-549, 2014.

LESTARI, A. S. R. D. et al. Glulam properties of fastgrowing species using mahogany tannin adhesive. BioResources, 10(4):7419-7433, 2015.

LIMA, N. N. et al. Propriedades físico-mecânicas de painéis LVL produzidos com três espécies amazônicas. Cerne, 19(3):407-413, 2013.

MALLO, M. F. L.; ESPINOZA, O. Awareness, perceptions and willingness to adopt cross-laminated timber by the architecture community in the United States. Journal of Cleaner Production, 94:198-210, 2015.
MARQUES, A. C. et al. Review on adhesives and surface treatments for structural applications: Recent developments on sustainability and implementation for metal and composite substrates. Materials, 13(24):5590, 2020.

MATOS, A. C. et al. Influência de diferentes composições de lâminas de Schizolobium parahyba var. amazonicum (Huber ex Ducke) Barneby e Pinus oocarpa var. oocarpa (Schiede ex Schltdl) para produção de compensados multilaminados. Scientia Forestalis, 47(124):799-810, 2019.

MENDES, R. F. et al. Qualidade de painéis aglomerados homogêneos produzidos com a madeira de clones de Eucalyptus urophylla. Cerne, 20(2):329-336, 2014.

MODES, K. S. et al. Wood quality of Pinus patula schltdl \& cham for the pulp production. Revista Árvore, 43(2):e430207, 2019

NAVARATNAM, S. et al. Bending and shear performance of Australian radiata pine cross-laminated timber. Construction and Building Materials, 232:117215, 2020.

PEREIRA, M. A. et al. Propriedades anatômicas, químicas e de densidade da madeira de Coffea arabica L. Cerne, 20(3):363-367, 2014.

PINATI, E. et al. Painéis compensados sarrafeados produzidos com Pinus oocarpa, Castilla uleie Acrocarpus fraxinifolius. Ciência da Madeira, 9(3):199-208, 2018.

QIAO, W. et al. Synthesis and characterization of phenolformaldehyde resin using enzymatic hydrolysis lignin. Journal of Industrial and Engineering Chemistry, 21:1417-1422, 2015.

RACHTANAPUN, P.; SATTAYARAK, T.; KETSAMAK, N. Correlation of density and properties of particleboard from coffee waste with urea-formaldehyde and polymeric methylene diphenyl diisocyanates. Journal of Composite Materials, 15(46):1839-1850, 2012.

RINGHOFER, A.; BRANDNER, R.; BLAB, H. J. Cross laminated timber (CLT): Design approaches for doweltype fasteners and connections. Engineering Structures, 171:849-861, 2018.

SEGUNDINHO, P. G. A. et al. Madeira lamelada colada (MLC) com Acacia mangium e adesivos estruturais glued laminated timber (GLULAM) with Acacia mangium and structural adhesives. Scientia Forestalis, 43(107): 533$540,2015$.

SHESHMANI, S. Effects of extractives on some properties of bagasse/high density polypropylene composite. Carbohydrate Polymers, 94(1):416-419, 2013. 
SILVEIRA, L. H. C.; REZENDE, A. V.; VALE, A. T. Teor de umidade e densidade básica da madeira de nove espécies comerciais amazônicas. Acta Amazônica, 43(2):179-184, 2013.

SKAAR, C. Water in wood. New York: Syracuse University, 1988. 263p.

SOARES, S. S. et al. Valorização do bagaço de cana-deaçúcar na produção de painéis aglomerados de baixa densidade. Ciência da Madeira, 8(2):64-73, 2017.

SOUZA, F.; DEL MENEZZI, C. H. S. Material properties and nondestructive evaluation of LVL made from Pinusoocarpa and P. kesiya. European Journal of Wood and Wood Products, 69:183-192, 2011.
TRIANOSKI, R. et al. Variação longitudinal da densidade básica da madeira de espécies de Pinus tropicais. Floresta, 43(3):503-510, 2013.

TSOUMIS, G. Science and technology of wood: Structure, properties and utilization. New York: Van Nastrnd Reinold, 1991. 494p.

VIVIAN, M. A. et al. Qualidade das madeiras de Pinus taeda e Pinus sylvestris para a produção de polpa celulósica kraft. Scientia orestalis, 48(105):183191, 2015.

ZANUNCIO, A. J. V. et al. Extractives and energetic properties of wood and charcoal. Revista Árvore, 38(2):369-374, 2014. 